\title{
THE IMPACT OF INVESTMENTS IN PERMANENT ASSETS ON THE INCREASE IN THE NUMBER OF EMPLOYEES AND THEIR SALARIES BY ENTREPRENEURIAL SECTORS
}

\section{INTRODUCTION}

This study of the effect of the growth of permanent assets on the number of employees during the period from 2014 to 2020 in Serbia revealed a high correlation between these two trends and pointed out that new investments in permanent assets are the most significant generator of the number of employees $(2,23)$.

This paper aimed to identify the impact of investments in permanent assets on the number of employees by sector and its impact on employee salaries. We assume that higher investment contributes to the increase in the number of employees and their wages and contributes to better economic development of that sector.

Permanent assets include tangible, intangible, and biological assets, long-term investments, and long-term receivables. All these assets represent the manufacturing capital. The term 'fixed assets' is also used as the synonym for permanent assets.

\section{LITERATURE REVIEW}

Theoretical literature often points out that the volume and the sign of the change in fixed asset investments effect on employment depend on the production structure and the share of capital technology and labor. However, empirical studies of the interdependence of fixed asset investments and job creation are relatively scarce and limited. Fanhui Fan and Li Jing

\section{SUMMARY}

Key words: Marginal investments; a marginal number of employees; entrepreneurial sector; Serbia.

This work aimed to identify the impact of investments in permanent assets on the number of employees by sector and its impact on employee salaries. We draw the data from the Financial Statements Annual Bulletin published by the Serbian Business Registers Agency, representing aggregated data of all enterprises in Serbia and their analysis by sectors. The data set spans the period from 2013 to 2020 . The results show a high positive correlation between investment in permanent assets and the number of employees in the manufacturing sector and information and communication sector, and a negative one in the agricultural industry. We did not find a significant correlation between investments in permanent assets and the number of employees with their salaries.

\footnotetext{
' Jozefina Beke-Trivunac,ALFA BK Univerzitet, Beograd. E-mail: jozefina.beke@live.com.

${ }^{2}$ Drinka Peković, ALFA BK Univerzitet, Beograd. E-mail: drinka.peković@alfa.edu.rs.
} 
(2011) found a high positive correlation between investments in fixed assets and industrial employment and a negative and low correlation between investments in fixed assets in agricultural production and employment in agriculture $(4,955)$.

For a better understanding of the effects of fixed asset investment, it is necessary to know their determinants. The results of most researchers show that the availability of financial resources has a significant impact on the volume of investments in fixed assets. Using a sample of high-tech firms in Portugal, Nunes et al. (2017) estimated that one percent growth of the firm's debt in the previous period affects the increase in the volume of fixed assets investments by 0.52 percentage points. On the other hand, the firm's age restricts investment in fixed assets (6, 178). Similar results have been found in other studies. For that reason, it is necessary to keep in mind that one of the essential preconditions for investments in fixed assets is long-term finance. According to Sommer (2021), firms with higher investments in fixed assets and long-term finance are more likely to increase employment by 0.77 percentage points. These firms are also more likely to invest in the training of production workers and the number of permanently employed workers, which contributes to improving the quality of employment (11, 16-18).

Due to the importance of the firm's access to long-term finance for the firm's development, considerable attention from analysts in the past years has been given to researching the effects of long-term credits, particularly in developing countries. However, several studies show that long-term credits have a positive impact on employment growth and salary growth in firms, but it is not statistically significant. In addition, the results indicate that short-term loans have a critical impact on employment growth $(12,230-232)$. Leon (2020) found similar results related to the effects of long-term credits and short-term credits on employment growth $(5,77)$.

The access to loans for investing in fixed assets varies depending on the size of the firm. Small and medium firms face several financial and institutional obstacles in external financing. However, the research results show that the access to loans for small and medium-sized enterprises, for finance investments in fixed assets among other things, contributes more to employment growth than is the case with large firms. According to Ayyagari et al. (2016), employment growth would be higher by 3.06 percentage points if a small or medium enterprise had access to a loan or line of credit from a financial institution, while employment growth in a large firm with access to a loan would be higher by 1.18 percentage point $(1,35)$. This can be explained 
by the fact that small and medium enterprises tend to be more labor-intensive than large firms. It can be assumed that the relaxation of financing constraints faced by firms in the financial market would positively affect employment growth. The research study shows that firms facing severe financial barriers have 1.5 percentage points lower job creation rate than firms without financial constraints $(3,16)$. However, in the same study, the authors find that the impact of financial obstacles on job creation rate depends on the degree of working capital external financing. The results show that there is no statistically significant effect of fixed capital investments on employment growth between the firms facing financial barriers and firms which are more dependent on external funding $(3,22)$.

\section{METHODOLOGY}

To determine the sources of financing investments in permanent assets, we drew the data from the Financial Statements Annual Bulletin published by the Serbian Business Registers Agency, which represents aggregated data of all enterprises which submitted their financial reports, according to the Law on Accounting from 2013. The data set spans the period from 2013 to 2020. The data include data from financial statements of all enterprises and their analysis by sectors of activities. (7-10)

The first step was to calculate the aggregated statements of changes in financial positions of all enterprises in Serbia over the period from 2013 to 2020 . The statement of changes in financial position is a statement of flows. It measures the changes that have taken place in the financial position of an entity between two balance sheet dates. It shows the source of funds and the application of funds during the period.

The calculated changes in the financial position showed to be a valuable source of data for further analysis. We selected three financial statement positions from the calculated data: (1) annual changes of the stated values of permanent assets, (2) annual changes of the stated values of own capital, and (3) annual changes of the stated values of long-term financial liabilities. One of the basic assumptions in financial analysis is that long-term (here permanent) assets shall be financed with long-term funds (own capital and long-term financial liabilities). Following that assumption, we compared the annual changes of own capital and long-term financial liabilities with the annual changes of the permanent assets. The second step of the research included the analysis of the same phenomena in ten entrepreneurial sectors, 
which comprise about $85 \%$ of all enterprises. Finally, we compared the trends of change in value of gross annual salaries per employee with the trend of increase of permanent assets and the kind of investment in permanent assets. This was a qualitative analysis of quantitative data. Relevant statistics was initially performed in MS Excel and once again in STATA. Our database is based on MS Excel, and usually includes small series not longer than eight years. MS Excel statistical functions can be easily applied during the analysis. For its robustness, we check some results in STATA if we find it convenient.

All financial data are presented in thousands of Serbian dinars.

We are aware of the limited time series of analyzed data. We also believe that the accounting information of presented book values is fair enough for this analysis.

\section{RESULTS AND DISCUSSION}

The sources of financing permanent investment regularly come from the increase of own capital (either from profit or from new payments by the founders) and the long-term finance, mainly loans. Occasionally, during a period of crisis, short-term financing may be used for providing investment in permanent or long-term assets. The economy of Serbia experienced a period of crisis in 2014 due to a catastrophic flood that lasted for more than a month and caused severe consequences on the economy at that time. Due to the above-mentioned flood, entrepreneurial capital suffered severe losses and investments in permanent assets were generally financed with short-term liabilities.

During the period from 2015 to 2020, the increase in permanent assets was financed from own capital and from long-term liabilities, mainly loans. During the first part of that period, enterprises invested their own money in new permanent assets. In 2019 and 2020, the usage of long-term loans increased considerably to $36 \%$ in 2019 and $73 \%$ in 2020.

Table 1: Aggregated changes in permanent assets, own capital, and liabilities during the period from 2013 to 2020 - All enterprises in Serbia

\begin{tabular}{|c|c|c|c|c|c|c|c|}
\hline & 2014 & 2015 & 2016 & 2017 & 2018 & 2019 & 2020 \\
\hline Net increase in permanent assets & 241.648.570 & 118.076.391 & 354.206.684 & 450.916 .793 & 406.426.291 & 789.867.257 & 467.238.089 \\
\hline $\begin{array}{l}\text { Increase campared to the previous } \\
\text { year in } \%\end{array}$ & $3 \%$ & $2 \%$ & $5 \%$ & $6 \%$ & $5 \%$ & $9 \%$ & $5 \%$ \\
\hline financed by: & & \multirow{3}{*}{ 206.124.364 } & \multirow{3}{*}{383.463 .277} & & \multirow{3}{*}{523.487 .446} & & \\
\hline 1. own capital & (260.078.509) & & & 407.067 .224 & & 502.061 .777 & 127.307.907 \\
\hline 2. Iong-term liabilities & 159.445 .738 & & & 43.849 .569 & & 287.805 .480 & 339.930 .182 \\
\hline 3. short-term liabiliteis & 342.281 .341 & (88.047.973) & $(29.256 .593)$ & - & $(117.061 .155)$ & & - \\
\hline Ratio: Capital / Permanent assets & $-108 \%$ & $175 \%$ & $108 \%$ & $90 \%$ & $129 \%$ & $64 \%$ & $27 \%$ \\
\hline
\end{tabular}


Investments in permanent assets of all enterprises increased continually on an annual basis from 2014 to 2020 between two and nine percent. At the same time, except in 2014, enterprises' capital also increased. In 2015, 2016, and 2018, the increase in own capital was high enough to finance the increase in permanent assets. In 2017, 2019, and 2020 the funds needed for investments in permanent assets included own capital and long-term liabilities. The usage of long-term liabilities for financing permanent assets increased significantly in 2019 and 2020.

Analyzed by sectors, the most significant shares of the investments in permanent assets changed on an annual basis. In 2014, 39\% of investments in permanent assets were related to the construction sector, and $18 \%$ to transportation and storage. This phenomenon may be attributed to the recovery from the consequences of the catastrophic flood that year. The most significant investments over the period were realized in the manufacturing sector $(16 \%)$, transportation and storage sector $(14 \%)$, construction sector $(11 \%)$, and agriculture, forestry, and fishing sector $(10 \%)$.

Table 2: Net increase/decrease in permanent assets by sectors

\begin{tabular}{|c|c|c|c|c|c|c|c|c|c|c|c|}
\hline Period & $\begin{array}{l}\text { A-Agriculture, } \\
\text { forestry and } \\
\text { fishing }\end{array}$ & B - Mining & $\begin{array}{c}\text { C - } \\
\text { Manufacturing }\end{array}$ & $\begin{array}{l}\text { D - Electricity, } \\
\text { gas, steam }\end{array}$ & $\begin{array}{l}\text { E - Water } \\
\text { supply }\end{array}$ & $\begin{array}{c}\mathrm{F}- \\
\text { Construction }\end{array}$ & $\begin{array}{c}\text { G - Wholesale } \\
\text { and retail } \\
\text { trade }\end{array}$ & $\begin{array}{c}\mathrm{H}- \\
\text { Transportatio } \\
\mathrm{n} \text { and storage }\end{array}$ & $\begin{array}{c}\text { I- } \\
\text { Accomodation } \\
\text { and food } \\
\text { service act. }\end{array}$ & $\begin{array}{c}\mathrm{J} \text { - Information } \\
\text { and } \\
\text { communicatio } \\
\mathrm{n}\end{array}$ & All enterprises \\
\hline 2014-2013 & 23.313 .614 & 23.496 .534 & $(10.189 .046)$ & 15.213 .774 & $(2.041 .440)$ & 95.133 .814 & $(8.159 .683)$ & \begin{tabular}{|l|}
43.012 .464 \\
\end{tabular} & 6.276 .930 & 4.354 .654 & 241.648 .570 \\
\hline Share & $10 \%$ & $10 \%$ & $-4 \%$ & $6 \%$ & $-1 \%$ & $39 \%$ & $-3 \%$ & $18 \%$ & $3 \%$ & $2 \%$ & $100 \%$ \\
\hline 2015-2014 & 83.387 .558 & (45.936.151) & 48.136 .506 & (32.889.592) & 5.918 .066 & (4.461.752) & 8.773 .953 & (82.945.718) & 8.081 .121 & 19.008 .609 & 118.076 .391 \\
\hline Share & $71 \%$ & $-39 \%$ & $41 \%$ & $-28 \%$ & $5 \%$ & $-4 \%$ & $7 \%$ & $-70 \%$ & $7 \%$ & $16 \%$ & $100 \%$ \\
\hline 2016-2015 & 8.394 .312 & (604.611) & 39.416 .255 & 27.180 .098 & 8.047 .633 & 32.510 .080 & $(1.502 .327)$ & 32.776 .808 & (3.781.609) & 5.690 .685 & 354.206 .684 \\
\hline Share & $2 \%$ & $0 \%$ & $11 \%$ & $8 \%$ & $2 \%$ & $9 \%$ & $0 \%$ & $9 \%$ & $-1 \%$ & $2 \%$ & $100 \%$ \\
\hline 2017-2016 & 105.418 .721 & 1.803 .147 & 101.174.021 & 131.771 .456 & 952.608 & 31.554 .245 & 30.579 .040 & 31.090 .919 & 8.768 .878 & 10.167 .622 & 450.916 .793 \\
\hline Share & $23 \%$ & $0 \%$ & $22 \%$ & $29 \%$ & $0 \%$ & $7 \%$ & $7 \%$ & $7 \%$ & $2 \%$ & $2 \%$ & $100 \%$ \\
\hline 2018-2017 & 44.143 .459 & 20.087 .561 & 39.547 .783 & 80.388 .981 & (21.530.391) & 40.439 .724 & 47.096 .614 & 89.054 .391 & 6.108 .260 & 46.047 .343 & 406.426 .291 \\
\hline Share & $11 \%$ & $5 \%$ & $10 \%$ & $20 \%$ & $-5 \%$ & $10 \%$ & $12 \%$ & $22 \%$ & $2 \%$ & $11 \%$ & $100 \%$ \\
\hline 2019-2018 & $(9.644 .602)$ & 32.390 .668 & 109.576 .439 & 36.817 .881 & 40.302 .447 & 72.087 .236 & 38.325 .757 & 180.096 .682 & 18.194 .823 & 111.353 .056 & 789.867 .257 \\
\hline Share & $-1 \%$ & $4 \%$ & $14 \%$ & $5 \%$ & $5 \%$ & $9 \%$ & $5 \%$ & $23 \%$ & $2 \%$ & $14 \%$ & $100 \%$ \\
\hline $2020-2019$ & 21.287 .784 & 58.468 .846 & 130.183 .075 & (57.694.134) & 17.356 .442 & 36.055 .020 & 51.082 .420 & 92.631 .845 & 24.237 .663 & 31.226 .849 & 467.238 .089 \\
\hline Share & $5 \%$ & $13 \%$ & $28 \%$ & $-12 \%$ & $4 \%$ & $8 \%$ & $11 \%$ & $20 \%$ & $5 \%$ & $7 \%$ & $100 \%$ \\
\hline $\begin{array}{l}\text { Total increase over } \\
\text { the period }\end{array}$ & 276.300 .846 & 89.705 .994 & 457.845 .033 & 200.788 .464 & 49.005 .365 & 303.318 .367 & 166.195 .774 & 385.717.391 & 67.886 .066 & 227.848 .818 & 2.828 .380 .075 \\
\hline Share & $10 \%$ & $3 \%$ & $16 \%$ & $7 \%$ & $2 \%$ & $11 \%$ & $6 \%$ & $14 \%$ & $2 \%$ & $8 \%$ & $100 \%$ \\
\hline
\end{tabular}

Source: Authors' calculation

In 2014 almost all enterprises financed their investments in permanent assets with their own capital. From 2015, the construction sector, transportation and storage sector, and accommodation and food services sector started to use long-term loans to finance investments in permanent assets.

Table 3: The structure of funds (own capital and long term liabilities) used to finance the increase of permanent assets, by sectors 
Table 3: The structure of funds (own capital and long term liabilities) used to finance the increase of permanent assets, by sectors

\begin{tabular}{|c|c|c|c|c|c|c|c|c|c|c|c|}
\hline Period & $\begin{array}{l}\text { A - Agriculture, } \\
\text { forestry and } \\
\text { fishing }\end{array}$ & B - Mining & \begin{tabular}{|l} 
C - \\
Manufacturing
\end{tabular} & $\begin{array}{l}\text { D - Electricity, } \\
\text { gas, steam }\end{array}$ & $\begin{array}{l}\text { E - Water } \\
\text { supply }\end{array}$ & $\begin{array}{l}\mathrm{F}- \\
\text { Construction }\end{array}$ & $\begin{array}{l}\text { G - Wholesale } \\
\text { and retail } \\
\text { trade }\end{array}$ & $\begin{array}{l}\mathrm{H} \text { - } \\
\text { Transportatio } \\
\text { n and storage }\end{array}$ & $\begin{array}{l}\text { I- } \\
\text { Accomodation } \\
\text { and food } \\
\text { service act. }\end{array}$ & $\begin{array}{l}\mathrm{J} \text { - Information } \\
\text { and } \\
\text { communicatio } \\
\mathrm{n}\end{array}$ & All \\
\hline \multicolumn{12}{|l|}{$2014-2013$} \\
\hline Own capital & $30 \%$ & & $100 \%$ & & $100 \%$ & $91 \%$ & & $100 \%$ & $100 \%$ & $100 \%$ & \\
\hline Long term liabilities & $6 \%$ & & & & & $1 \%$ & & & & & $66 \%$ \\
\hline \multicolumn{12}{|l|}{$2015-2014$} \\
\hline Own capital & $92 \%$ & $84 \%$ & $89 \%$ & $100 \%$ & $100 \%$ & $100 \%$ & $100 \%$ & & & & $100 \%$ \\
\hline Long term liabilities & $8 \%$ & & & & & & & & $38 \%$ & & \\
\hline \multicolumn{12}{|l|}{$2016-2015$} \\
\hline Own capital & $100 \%$ & & $100 \%$ & & $41 \%$ & $32 \%$ & & $9 \%$ & $35 \%$ & $100 \%$ & $100 \%$ \\
\hline Long term liabilities & & & & & & $68 \%$ & & $41 \%$ & $44 \%$ & & \\
\hline \multicolumn{12}{|l|}{$2017-2016$} \\
\hline Own capital & $99 \%$ & $100 \%$ & $100 \%$ & $91 \%$ & & $51 \%$ & $32 \%$ & $50 \%$ & $10 \%$ & $100 \%$ & $90 \%$ \\
\hline Long term liabilities & $1 \%$ & & & & $52 \%$ & $49 \%$ & $68 \%$ & & $9 \%$ & & $10 \%$ \\
\hline \multicolumn{12}{|l|}{$2018-2017$} \\
\hline Own capital & $20 \%$ & $100 \%$ & $100 \%$ & $8 \%$ & $100 \%$ & $43 \%$ & $100 \%$ & $69 \%$ & $80 \%$ & $55 \%$ & $100 \%$ \\
\hline Long term liabilities & $80 \%$ & & & $61 \%$ & & $57 \%$ & & $31 \%$ & & & \\
\hline \multicolumn{12}{|l|}{$2019-2018$} \\
\hline Own capital & & $100 \%$ & $100 \%$ & $100 \%$ & $84 \%$ & $66 \%$ & $100 \%$ & $15 \%$ & $31 \%$ & $21 \%$ & $64 \%$ \\
\hline Long term liabilities & $100 \%$ & & & & $12 \%$ & $34 \%$ & & $15 \%$ & $43 \%$ & $58 \%$ & $22 \%$ \\
\hline \multicolumn{12}{|l|}{$2020-2019$} \\
\hline Own capital & $98 \%$ & & & $100 \%$ & & $100 \%$ & $100 \%$ & & $15 \%$ & $100 \%$ & $27 \%$ \\
\hline Long term liabilities & & $39 \%$ & $88 \%$ & & $100 \%$ & & & $11 \%$ & $85 \%$ & & $77 \%$ \\
\hline
\end{tabular}

Note: If the increase in own capital is higher than or equal to the increase in permanent assets, we assume that the total growth is financed by own money $(100 \%)$. If an increase in own capital is less than the increase in permanent assets, an increase financed with long-term liabilities is allocated to the increase in capital up to $100 \%$. If the sum of both percentages is less than $100 \%$, the difference of growth of permanent assets is financed with short-term financial liabilities.

The most significant increase in the number of employees from 2014 to 2020 can be seen in the manufacturing sector, followed by the wholesale and retail trade sector, information and communication sector, and construction sector. On the other hand, mining and agriculture, forestry, and fishing sectors experienced significant negative migration of employees.

Table 4: Increase/decrease in the number of employees by sectors

\begin{tabular}{|c|c|c|c|c|c|c|c|c|c|c|c|}
\hline Period & $\begin{array}{c}\text { A - Agriculture, } \\
\text { forestry and } \\
\text { fishing }\end{array}$ & B - Mining & $\begin{array}{c}\text { C- } \\
\text { Manufacturing }\end{array}$ & $\begin{array}{c}\text { D - Electricity, } \\
\text { gas, steam }\end{array}$ & $\begin{array}{l}\text { E - Water } \\
\text { supply }\end{array}$ & $\begin{array}{c}\mathrm{F}- \\
\text { Construction }\end{array}$ & $\begin{array}{c}\mathrm{G} \text { - Wholesale } \\
\text { and retail } \\
\text { trade }\end{array}$ & $\begin{array}{c}\mathrm{H}- \\
\text { Transportatio } \\
\mathrm{n} \text { and storage }\end{array}$ & $\begin{array}{c}\mathrm{I}- \\
\text { Accomodation } \\
\text { and food } \\
\text { service act. }\end{array}$ & $\begin{array}{c}\mathrm{J}-\text { Information } \\
\text { and } \\
\text { communicatio } \\
\mathrm{n}\end{array}$ & All enterprises \\
\hline 2014-2013 & (1.656) & 1.488 & (9.071) & (610) & (1.104) & (3.404) & (3.234) & (56) & (799) & (650) & (18.839) \\
\hline Share & $9 \%$ & $-8 \%$ & $48 \%$ & $3 \%$ & $6 \%$ & $18 \%$ & $17 \%$ & $0 \%$ & $4 \%$ & $3 \%$ & $100 \%$ \\
\hline 2015-2014 & (887) & (13.350) & 1.303 & 9.595 & (354) & (1.515) & 6.279 & 799 & 3.676 & 4.653 & 14.839 \\
\hline Share & $-6 \%$ & $-90 \%$ & $9 \%$ & $65 \%$ & $-2 \%$ & $-10 \%$ & $42 \%$ & $5 \%$ & $25 \%$ & $31 \%$ & $100 \%$ \\
\hline 2016-2015 & (1.284) & (195) & 13.662 & 3.539 & 97 & 759 & 8.653 & 1.634 & $(1.735)$ & - & 45.157 \\
\hline Share & $-3 \%$ & $0 \%$ & $30 \%$ & $8 \%$ & $0 \%$ & $2 \%$ & $19 \%$ & $4 \%$ & $-4 \%$ & $0 \%$ & $100 \%$ \\
\hline 2017-2016 & 9 & (111) & 24.317 & (1.336) & (170) & 769 & 4.247 & 1.427 & 3.909 & 2.462 & 45.050 \\
\hline Share & $0 \%$ & $0 \%$ & $54 \%$ & $-3 \%$ & $0 \%$ & $2 \%$ & $9 \%$ & $3 \%$ & $9 \%$ & $5 \%$ & $100 \%$ \\
\hline 2018-2017 & (101) & 1.393 & 18.819 & (1.006) & 548 & 4.329 & - & 517 & 3.065 & 2.250 & 50.120 \\
\hline Share & $0 \%$ & $3 \%$ & $38 \%$ & $-2 \%$ & $1 \%$ & $9 \%$ & $0 \%$ & $1 \%$ & $6 \%$ & $4 \%$ & $100 \%$ \\
\hline 2019-2018 & (816) & 709 & 12.554 & (912) & 113 & 6.086 & 13.961 & 1.114 & 3.030 & 2.510 & 43.135 \\
\hline Share & $-2 \%$ & $2 \%$ & $29 \%$ & $-2 \%$ & $0 \%$ & $14 \%$ & $32 \%$ & $3 \%$ & $7 \%$ & $6 \%$ & $100 \%$ \\
\hline 2020-2019 & (739) & 2.138 & 17.015 & (571) & (548) & 3.543 & 4.502 & 2.023 & (458) & 11.729 & 43.592 \\
\hline Share & $-2 \%$ & $5 \%$ & $39 \%$ & $-1 \%$ & $-1 \%$ & $8 \%$ & $10 \%$ & $5 \%$ & $-1 \%$ & $27 \%$ & $100 \%$ \\
\hline Total 2014-2020 & (3.827) & (9.305) & 63.353 & 10.645 & (144) & 13.202 & 33.395 & 6.087 & 7.578 & 21.142 & 196.843 \\
\hline
\end{tabular}

To measure the impact of the investments in permanent assets on the number of employees, we used the coefficient of correlation. The correlation coefficient between the investments in permanent assets and the increase in the number of employees 
is significant only in the manufacturing sector -0.69 , while the one between the investments in the permanent assets and the growth of average annual gross salaries is 0.59 .

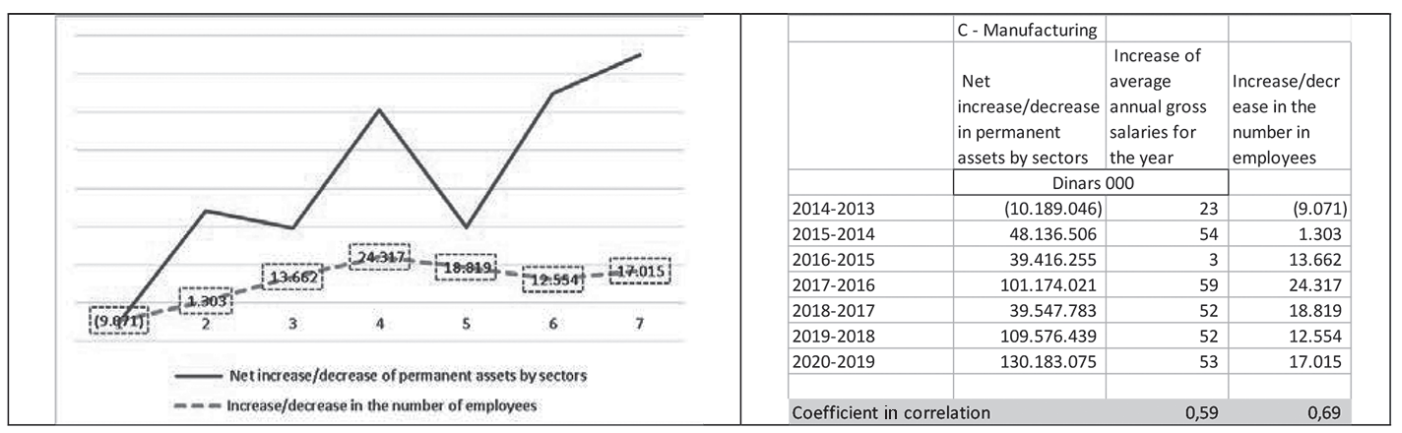

Source: Authors' calculation

Figure 1: Movements in annual investments in permanent assets and annual increase in the number of employees in the manufacturing sector

Different phenomena were found in the agricultural sector and information and communication sector. Although investments in permanent assets in the agrarian sector continually increase, the number of employees in that sector constantly decreases. The coefficient of correlation between investments in permanent assets and the change in the number of employees is 0.55 , i.e. investments of fifty million dinars (EUR 400,000) contribute to a decrease in the number of employees by one. On the other hand, investments of ten million dinars (EUR 82,000) in the information and communication sector contribute to the increase in the number of employees by one. The reasonable explanation for the ITC sector phenomenon is that this sector is based on knowledge, but the value of knowledge is not recognized in financial statements.

All sectors experienced an increase in salaries over the period. The highest growth in salaries was realized in the information and communication sector. Electricity, gas and steam and construction sectors were slightly above the average. The growth in salaries in the agriculture, forestry and fishing sector, and wholesale and retail trade were about average, in manufacturing, water supply, and transportation and storage sector were slightly below average, and in mining and accommodation and food service activities sectors were far below average. We have not noticed any correlation between the investment in permanent assets, the increase in the number of employees, and the increase in salaries. 
Table 5: Annual increase in average gross salaries

\begin{tabular}{|c|c|c|c|c|c|c|c|c|c|c|c|}
\hline Period & $\begin{array}{l}\text { A - Agriculture, } \\
\text { forestry and } \\
\text { fishing }\end{array}$ & B - Mining & $\begin{array}{l}\text { C. } \\
\text { Manufacturing }\end{array}$ & $\begin{array}{l}\text { D - Electricity, } \\
\text { gas, steam }\end{array}$ & $\begin{array}{l}\text { E - Water } \\
\text { supply }\end{array}$ & $\begin{array}{l}\text { F- } \\
\text { Construction }\end{array}$ & $\begin{array}{l}\text { G - Wholesale } \\
\text { and retail } \\
\text { trade }\end{array}$ & $\begin{array}{l}\mathrm{H} \text { - } \\
\text { Transportatio } \\
\text { n and storage }\end{array}$ & $\begin{array}{l}\text { I- } \\
\text { Accomodation } \\
\text { and food } \\
\text { service act. }\end{array}$ & $\begin{array}{l}\mathrm{J} \text { - Information } \\
\text { and } \\
\text { communicatio } \\
\mathrm{n}\end{array}$ & All \\
\hline $2014-2013$ & 22 & 24 & 23 & 57 & 28 & 94 & 28 & 25 & 12 & 145 & 35 \\
\hline $2015-2014$ & 20 & 48 & 54 & 446 & 7 & 39 & 24 & 75 & 32 & 1 & 4 \\
\hline 2016-2015 & 15 & 20 & 3 & 686 & 1 & 73 & 41 & 138 & 105 & 200 & 53 \\
\hline 2017-2016 & 30 & 96 & 59 & 175 & 71 & 89 & 52 & 30 & 11 & 81 & 60 \\
\hline 2018-2017 & 132 & 34 & 52 & 6 & 37 & 47 & 112 & 54 & 35 & 213 & 58 \\
\hline 2019-2018 & 39 & 197 & 52 & 58 & 62 & 163 & 30 & 90 & 57 & 102 & 75 \\
\hline $2020-2019$ & 103 & 6 & 53 & 38 & 133 & 62 & 78 & 43 & 16 & 221 & 73 \\
\hline Total 2013-2020 & 361 & 202 & 296 & 487 & 339 & 421 & 366 & 306 & 127 & 960 & 359 \\
\hline
\end{tabular}

Source: Authors' calculation

Statistical results calculated in Excel are additionally confirmed in STATA program by using absolute nominal values of permanent assets, the number of employees, and long-term liabilities (instead of changes as presented in tables 1 to 5).

Table 6: The correlation between employment, permanent assets, and long-term liabilities

\begin{tabular}{|l|c|c|c|c|c|c|c|c|c|}
\hline & \multicolumn{3}{|c|}{ Agriculture } & \multicolumn{3}{c|}{ Manufacturing } & \multicolumn{3}{c|}{$\begin{array}{l}\text { Information and } \\
\text { communication }\end{array}$} \\
\hline Variable & EMP & PA & LTL & EMP & PA & LTL & EMP & PA & LTL \\
\hline EMP & 1.000 & & & 1.000 & & & 1.000 & & \\
\hline PA & $-0.913^{*}$ & 1.000 & & $0.980^{*}$ & 1.000 & & $0.926^{*}$ & 1.000 & \\
\hline LTL & $-0.900^{*}$ & $0.949^{*}$ & 1.000 & $0.749^{*}$ & $0.800^{*}$ & 1.000 & 0.564 & 0.578 & 1.000 \\
\hline
\end{tabular}

Note 1: EMP - Employees; FA - Permanent assets; LTL - Long-term loans. Note 2: ${ }^{*}$ Represents statistical significance at 5 percent

Source: Authors' calculation

The results in Table 6 show the correlation coefficient between the number of employees, permanent assets, and longterm liabilities in three entrepreneurial sectors calculated in STATA program. There is a positive, high correlation between employment and permanent assets in the manufacturing industry, statistically significant. The investments in permanent assets have been accompanied by an increase in the number of employees. In addition, the increase in long-term liabilities is connected with employment growth, and this relationship is statistically significant. The positive, high, and statistically significant relationship between the number of employees and permanent assets can be seen in the information and communication sector as well. The relationship between employment and long-term liabilities is positive but moderate, and it is not statistically significant.

However, the correlation coefficient between employment and permanent assets is negative, high, and statistically significant in agriculture. It means that investments in permanent assets are related to a decrease in the number of employees in agriculture. This result confirms that investment in permanent assets contributes to the improvement of agriculture technology 
but reduces the need for labor. In addition, the increase in the long-term liabilities is related to the decrease in employment. We can also see that the correlation between permanent assets and long-term liabilities is positive, high, and statistically significant, like in manufacturing, indicating the use of long-term finance for permanent asset investments. On the other hand, the correlation between permanent assets and long-term liabilities in the information and communication sector is positive but statistically insignificant.

Table 7: Partial correlation between employment and permanent assets

\begin{tabular}{|l|l|l|l|l|l|}
\hline \multicolumn{2}{|c|}{ Agriculture } & \multicolumn{2}{c|}{ Manufacturing } & \multicolumn{2}{c|}{$\begin{array}{l}\text { Information and } \\
\text { communication }\end{array}$} \\
\hline $\begin{array}{l}\text { Partial } \\
\text { correlation }\end{array}$ & $\begin{array}{l}\text { Significance } \\
\text { Value }\end{array}$ & $\begin{array}{l}\text { Partial } \\
\text { correlation }\end{array}$ & $\begin{array}{l}\text { Significance } \\
\text { Value }\end{array}$ & $\begin{array}{l}\text { Partial } \\
\text { correlation }\end{array}$ & $\begin{array}{l}\text { Significance } \\
\text { Value }\end{array}$ \\
\hline-0.429 & 0.337 & 0.957 & 0.001 & 0.891 & 0.007 \\
\hline
\end{tabular}

Given that long-term liabilities have an impact on both the number of employees and permanent assets, it is necessary to determine the correlation between employment and permanent assets, excluding the impact of long-term liabilities. For that reason, the partial correlation coefficient was calculated in STATA. The results in Table 7 confirm a positive and high correlation between employment and permanent assets in the manufacturing and information and communication sectors, without the impact of long-term liabilities on both variables. We can conclude that the increase in the number of employees is related to investments in permanent assets, and this relationship is statistically significant at a 1 percent level. On the other hand, the partial correlation coefficient between employment and permanent assets in agriculture is negative and lower than the correlation coefficient. We can conclude that investments in permanent assets are related to the decrease in employment in agriculture, but this relation, without the impact of long-term liabilities, is statistically insignificant.

\section{CONCLUSION}

We assumed that the higher investment contributes to the increase in the number of employees and their salaries and contributes to better economic development of that sector.

Aggregated changes in permanent assets of all enterprises in Serbia show their continual increase. During the period from 2015 to 2020 permanent assets were financed with capital and from long-term loans. During the first part of that period, permanent assets were funded mainly with their capital. In 2019 and 2020, the usage of long-term loans increased considerably to $36 \%$ in 2019 and $73 \%$ in 2020 . 
UČINAK ULAGANJA

U STALNA SREDSTVA NA POVEĆANJE BROJA ZAPOSLENIH I NJIHOVIH ZARADA U
PREDUZETNIM
SEKTORIMA

\section{REZIME}

Ključne reči: Marginalna ulaganja; marginalan broj zaposlenih; privredna društva; Srbija.

Cilj ovog rada je da prepozna učinak ulaganja u stalna sredstva na broj zaposlenih po sektorima, i na visinu zarada zaposlenih. Podaci za rad preuzeti su iz Godišnjeg biltena finansijskih izveštaja koji izdaje Agencija za privredne registre Republike Srbije. Baza podataka obuhvata zbirne podatke svih privrednih društva u Srbiji i njihovu analitiku po sektorima delatnosti, za period od 2013. do 2020. godine. Rezultati ispitivanja pokazuju visoku pozitivnu korelaciju između ulaganja u stalna sredstva i broja zaposlenih u prerađivačkoj delatnosti i delatnosti informisanja i komunikacije, i negativnu korelaciju u delatnosti poljoprivrede. Nije utvrđena značajna korelacija između ulaganja u stalna sredstva i rasta broja zaposlenih sa rastom njihovih zarada.
The investments in permanent assets were accompanied by the increase in the number of employees and the increase in long-term liabilities, at a statistically significant level. The positive, high, and statistically significant relationship between the number of employees and permanent assets was also found in the information and communication sector. The relationship between employment and long-term liabilities is also positive but moderate, not statistically significant. In the agricultural industry, the correlation between the increase in employment and the increase in permanent assets is negative. It means that investments in permanent assets in agriculture resulted in a decrease in the number of employees in that sector.

We have not noticed a significant correlation between the investment in permanent assets, the increase in the number of employees, and their salaries.

\section{LITERATURE}

1. Ayyagari, M., Juarros, P., Peria, M., Singh, S. (2016) Access to Finance and Job Growth: Firm- Level Evidence across Developing Countries, Policy Research Working Paper No. 7604, World Bank Group.

2. Beke, J., Stoiljković, B., Peković, D. (2021) Investments in fixed assets impact on the employment growth in the Republic of Serbija, Revizor, Vol. 24, No. 94, 17-23.

3. Dao, M.C., Liu, Q.L. (2017). Finance and Employment in Developing Countries: The Working Capital Channel. IMF Working Paper No. 17/189.

4. Fan, F., Jing, L. (2011). Study of Fixed Assets Investment's Effect on the Employment of Three Industries, Proceedings of the $7^{\text {th }}$ International Conference of Innovation \& Management, 951-956. https:// www.pucsp.br/icim/ingles/downloads/papers_2010/part_5/58 Study\%20of\%20Fixed\%20Assets\%20Investment_s\%20Effect\% 20 on\%20the\%20Employment\%20of.pdf

5. Leon, F. (2020). The provision of long-term credit and firm growth in developing countries. Economic Modeling, Vol. 90, 66-78. https:// doi.org/10.1016/j.econmod.2020.04.023

6. Nunes, P., Serrasqueiro, Z. \& Matos, A. (2017). Determinants of invested fixed assets and in intangible assets for high-tech firms. Journal of International Studies, 10 (1), 173-179.

7. Serbian Business Registers Agency, Financial Statements Annual Bulletin 2020, Belgrade, April 2021. 1

8. Serbian Business Registers Agency, Financial Statements Annual Bulletin 2018, Belgrade, April 2019. 2

9. Serbian Business Registers Agency, Financial Statements Annual Bulletin 2016, Belgrade, April 2017. 3

10. Serbian Business Registers Agency, Financial Statements Annual Bulletin 2014, Belgrade, July 2015. 4

11. Sommer, C. (2021). The impact of patient capital on job quality, investments and firm performance: Cross-country evidence on longterm finance, Discussion Paper No. 6/2021, Deutsches Institut für Entwicklungspolitik (DIE), Bonn.

12. Watson, J. (2020). The Provision of Long-Term Credit and Firm Growth in Developing Countries. Asian Journal of Economics and Empirical Research, 7 (2), 224-234. 